\title{
Using Information Literacy Standards To Improve Geoscience Courses
}

\author{
Aimée L. DeChambeau Science and Technology Library, The University of Akron, Akron OH \\ 44325-3907, aimee@uakron.edu \\ Ira D. Sasowsky \\ Office for Terrestrial Records of Environmental Change, Department of Geology \\ \& Center for Environmental Studies, The University of Akron, Akron OH \\ 44325-4101, ids@uakron.edu
}

\begin{abstract}
Information literacy (IL) is the set of skills that enables a person to find, evaluate, and use information. Although IL is important in the geosciences, it is hard to teach because the information comes in so many forms. Most geoscience courses include work that implicitly addresses some IL issues. However, because of the importance of IL, it is worthwhile to explicitly include it as part of the curriculum. The Association of College and Research Libraries has developed Information Literacy Standards for Higher Education that may be used to assess an individual's level of information literacy. We introduce a method for incorporating IL into the classroom experience by mapping an assignment to the ACRL standards. By using our method, an instructor, with or without the aid of a librarian, can easily implement IL in the classroom, providing both immediate and long-term benefits to the student.

Keywords: Education - Graduate, Education, Science
\end{abstract}

\section{INTRODUCTION}

Information literacy (IL), sometimes called information competency, is a set of skills that enables a person to recognize a need for information, locate and use resources to fulfill the information need, effectively evaluate and synthesize the information found, and apply it in an ethical and responsible manner. IL is particularly important in the geosciences because information is the commodity of the discipline. However, it is also particularly challenging to develop IL competency in the discipline. Bichtelor (1985), paraphrasing Wheeler's 1974 testimony before the National Commission on Libraries and Information Science, concludes that difficulties encountered in the access and use of geoscience information may be caused by: "(a) the broad scope of the fields within the geosciences; (b) the great variety of formats which must be used; (c) the multitude of relevant information sources; and (d) the value of older literature which must continue to be accessed and retrieved."

Figure 1 displays a comprehensive view of the realm of geoscience information. Information seekers take a variety of paths (based on background, expertise, and available resources) to obtain the material they need. The staggering breadth of search methods, information products, and information types underscores the importance of developing IL skills early in a career.

In this paper we introduce a method to help instructors incorporate IL into the classroom experience by mapping an assignment to the Association of College and Research Libraries (ACRL) standards. IL skills that the students acquire in one class provide a direct benefit to them in other classes and prepare them to gather, critically evaluate, and incorporate information from a wide range of sources.

These skills provide a solid basis for people to become lifelong learners. The American Library Association's 1989 Presidential Committee on Information Literacy report indicates that people who are information literate are people who have learned how to learn. Moreover, they know how to learn because they are familiar with the organization and location of information and can retrieve and apply it in such a way that others can learn from them. The Association of College and Research Libraries (ACRL, 2000) has developed Information Literacy Standards for Higher Education which may be used to assess an individual's level of information literacy. The five ACRL Information Literacy Standards are reproduced below.

\section{An information literate student:}

1) Determines the nature and extent of the information needed.

2) Accesses needed information effectively and efficiently.

3) Evaluates information and its sources critically and incorporates selected information into his or her knowledge base and value system.

4) Individually, or as a member of a group, uses information effectively to accomplish a specific purpose.

5) Understands many of the economic, legal, and social issues surrounding the use of information and accesses and uses information ethically and legally.

Each of the ACRL Standards is accompanied by performance indicators and associated outcomes. Outcomes in the ACRL standards include both lower and higher order thinking skills, as per Bloom's taxonomy (ACRL, 2000). For example, a performance indicator for Standard 1 states that the information literate student defines and articulates the need for information; an associated outcome is that the student develops a thesis statement and formulates questions based on the information need. In this paper we introduce an easy method for integrating information literacy skills into the classroom experience by mapping an assignment to the ACRL standards.

\section{METHODS TO DEVELOP COMPETENCY}

Many programs of library instruction, particularly for lower level undergraduates, have followed the pattern of tours, treasure hunts, and occasionally a single class period bibliographic instruction (BI) session. This is admirable, but library tours only show students where items are located physically, and out-of-context BI sessions are of very limited use in teaching students the actual skills they will need. Learning should be based on real-world information resources and, rather than being 


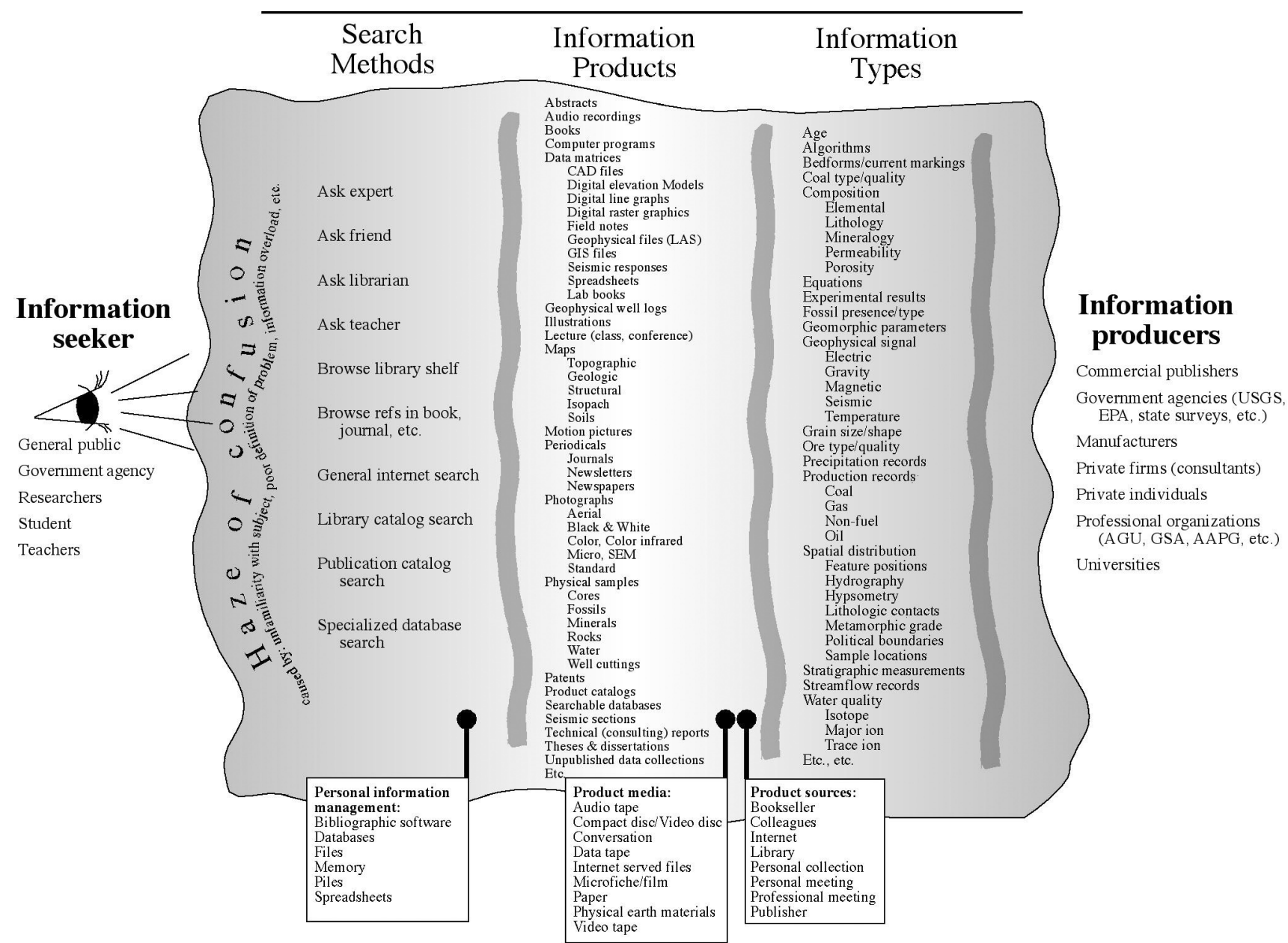

Figure 1. The realm of geoscience information. Information flows from Producers to Seekers, through a variety of methods and with a number of difficulties. Transfer of information occurs by Information Products, which take many forms. Methods, Products, and Types listed are representative; there are many others.

fragmented and passive, it should be active and integrated (ALA, 1989). Anecdotal evidence, from discussions at professional meetings and seminars, suggests that many instruction librarians prefer to move away from traditional 50-minute lectures and toward integration with course curricula. In fact, Stoan (1984) states this best by saying: "[i]nstruction in bibliographic resources is useless unless wedded to a course project in which students are simultaneously acquiring subject knowledge and direction from the professor and bibliographic skills from the librarian."

Most geoscience courses already incorporate features that increase information competency in students. That is, students must acquire, manage, synthesize, and communicate information and data. However, because IL is so critical, it is useful to explicitly focus course features to include an IL function and to measure it as such. This can be done in a graduated fashion, in courses at all levels, and with minimal effort on the part of the instructor. The benefits that the students gain from these activities will improve their performance in the immediate class, and in following classes. IL is a skill set for lifelong learning.

IL goes beyond libraries and library research; it includes the discovery, assessment, management, and use of information of all types. Libraries and library resources, however, provide an excellent laboratory for developing IL skills in students because of their focus on information. In addition, subject and instruction librarians - as information experts - can be invaluable in assisting geoscience faculty in integrating IL components into students' university experience.

One method for assessing the level of IL required by a particular course, and to identify areas for increasing and fostering IL skills, is to map the coursework to the ACRL Information Literacy Competencies Standards. A copy of the complete standards is available from the ACRL Information Literacy website: http://www. csusm.edu/acrl/il/toolkit/standards.html. Instructors can look at the standards and identify how course exercises, assignments, and lectures correspond to the performance indicators and outcomes outlined in the standards. In the following section we examine an example assignment in light of the ACRL Standards.

\section{MAPPING AN ASSIGNMENT TO THE ACRL STANDARDS}

Our example assignment requires that each student locate and retrieve two refereed journal articles about "evolution and the geologic record". The student then writes a 2-3 page paper comparing and contrasting the 


\begin{tabular}{|c|c|c|}
\hline ACRL Outcome: & Assignment component: & Measurements: \\
\hline Develop, modify, reevaluate thesis & $\begin{array}{l}\text { The basic topic is assigned, but } \\
\text { students can still choose some } \\
\text { aspect of "evolution and the } \\
\text { geologic record" - e.g., social vs. } \\
\text { scientific perspective, etc. }\end{array}$ & $\begin{array}{l}\text { - Initial and revised thesis } \\
\text { statements show appropriate } \\
\text { narrowing or broadening of } \\
\text { scope }\end{array}$ \\
\hline $\begin{array}{l}\text { Know how information is } \\
\text { produced, organized, disseminated }\end{array}$ & $\begin{array}{l}\text { Assignment requires use of } \\
\text { refereed articles, rather than } \\
\text { general interest or news. }\end{array}$ & $\begin{array}{l}\text { - Correctly differentiates the } \\
\text { various types of articles } \\
\text { - Identifies and uses appropriate } \\
\text { indexing resources to locate } \\
\text { articles } \\
\text { - Chooses appropriate refereed } \\
\text { articles } \\
\end{array}$ \\
\hline Define a realistic plan and timeline & $\begin{array}{l}\text { Are sufficient articles available at } \\
\text { hand? }\end{array}$ & $\begin{array}{l}\text { - Obtains articles in time } \\
\text { - Plans appropriately for obtaining } \\
\text { articles that are not immediately } \\
\text { at-hand (e.g., Interlibrary Loan } \\
\text { requests) }\end{array}$ \\
\hline
\end{tabular}

Table 1. Determining the nature and extent of the information need. Note that the Outcomes are drawn from the 2000 ACRL Standards.

articles. The trick in mapping the assignment to the standards is to gauge the extent to which IL skills are incorporated. Tables 1-5 identify explicit and implicit components of the assignment and provide examples of measurements that can be checked as milestones at various stages between the time the assignment is presented to the class and when the final paper is due. Making various stages of the assignment more explicit, and measuring them as such, helps students to more fully understand the stages involved in the process of gathering and using information. The sample assignment, as written, makes only 4 things explicit:

- Locate two refereed journal articles

- The topic of the articles must be evolution and the geologic record

- Write a 2-3 page paper

- Compare and contrast the articles.

When we examine the assignment in light of the ACRL standards, we can see that it also implies that the student must recognize the need for particular information, locate and use resources to fulfill the information need, effectively evaluate and synthesize the information found, and then apply it in an ethical and responsible manner. It is important to note that this example is similar to the type of assignment, across disciplines, that students routinely bring to the library without having had additional instruction or direction in the implicit aspects mentioned above.

In the tables that follow the outcomes are drawn from the ACRL standards. The assignment components relate directly to the example assignment, and the measurements are illustrative of what an instructor can look for when mapping this assignment to the standards.

\section{Standard 1: Determining the nature and extent of the information need}

ACRL Standard 1 indicates that an information literate student is able to determine the nature and extent of an information need. A sampling of the outcomes associated with this standard's performance indicators are presented in Table 1. In our example, the topic is identified for the students. However, they are probably not prepared to handle the quantity of information they will encounter when looking for specific articles to compare. Few early-year students will know the difference between a refereed journal article and one in a popular or trade magazine. Finally, students have a great deal of difficulty formulating reasonable thesis statements to guide their searches, and are unskilled in modifying the focus if they find too much or too little information. Example measurements presented in Table 1 can be checked as IL milestones at various stages between the time the assignment is presented to the class and when the final paper is due.

\section{Standard 2: Accessing needed information effectively and efficiently}

ACRL Standard 2 indicates that an information literate student accesses needed information effectively and efficiently. Sample outcomes are presented in Table 2. Accessing information effectively might be the crucial skill that most often falls through the proverbial crack. Most first- and second-year students have little or no experience in locating articles within the journal literature. They generally require guidance in using the university or college library, and specifically in the use of the appropriate indexing and abstracting products available to them (such as GeoRef). Understanding differences in search methods, for both paper indexes as well as electronic, is crucial for conducting efficient and productive searches. Finally, it is important that students learn how to easily locate both physical and electronic copies of journals in their school's library. Note that most of the assignment components listed in Table 2 are implicit rather than explicit.

\section{Standard 3: Critically evaluating information and sources from which it is gathered}

ACRL Standard 3 addresses the critical evaluation of information and the sources from which it is gathered, as well as the incorporation of information into a student's knowledge base and value system. The example assignment to compare and contrast has an inherent 


\begin{tabular}{|c|c|c|}
\hline Outcome: & Assignment component: & Measurements: \\
\hline $\begin{array}{l}\text { Investigate information retrieval } \\
\text { systems }\end{array}$ & $\begin{array}{l}\text { Locate the most appropriate } \\
\text { information retrieval system to use } \\
\text { based on the working thesis } \\
\text { statement }\end{array}$ & $\begin{array}{l}\text { - Uses GeoRef, GeoBASE and/or } \\
\text { other appropriate systems to } \\
\text { search for citations } \\
\text { - Uses JStor and other appropriate } \\
\text { full-text databases to retrieve } \\
\text { online articles } \\
\text { - Briefly states justification for } \\
\text { using a particular database }\end{array}$ \\
\hline $\begin{array}{l}\text { Select efficient and effective } \\
\text { approaches to accessing the } \\
\text { information }\end{array}$ & $\begin{array}{l}\text { Use indexes to locate information, } \\
\text { rather than simply browsing the } \\
\text { shelf }\end{array}$ & $\begin{array}{l}\text { - Uses GeoRef, GeoBASE and/or } \\
\text { other appropriate systems to } \\
\text { search for citations } \\
\text { - Uses JStor and other appropriate } \\
\text { full-text databases to retrieve } \\
\text { online articles } \\
\text { - Uses the library catalog to } \\
\text { determine availability of journal } \\
\text { titles in the local collection }\end{array}$ \\
\hline $\begin{array}{l}\text { Identify keywords, synonyms, and } \\
\text { related words appropriate for } \\
\text { searching }\end{array}$ & Generates a list of search terms & $\begin{array}{l}\text { - Brainstorms list of keywords for } \\
\text { searching }\end{array}$ \\
\hline $\begin{array}{l}\text { Select appropriate controlled } \\
\text { vocabulary }\end{array}$ & $\begin{array}{l}\text { Understands and applies concept } \\
\text { of controlled vocabulary }\end{array}$ & $\begin{array}{l}\text { - Uses thesauri and other methods } \\
\text { for determining controlled } \\
\text { vocabulary }\end{array}$ \\
\hline $\begin{array}{l}\text { Construct appropriate search } \\
\text { strategies; uses various systems to } \\
\text { retrieve information }\end{array}$ & $\begin{array}{l}\text { Understands and applies Boolean } \\
\text { logic, truncations, etc., when } \\
\text { appropriate }\end{array}$ & - Documents search strategy \\
\hline $\begin{array}{l}\text { Assess quantity, quality, and } \\
\text { relevance of search results }\end{array}$ & $\begin{array}{l}\text { Broadens or narrows search as } \\
\text { necessary }\end{array}$ & - Documents search strategy \\
\hline $\begin{array}{l}\text { Revise and re-executes search as } \\
\text { necessary }\end{array}$ & $\begin{array}{l}\text { Revises search strategy and terms } \\
\text { when necessary }\end{array}$ & - Documents search strategy \\
\hline $\begin{array}{l}\text { Record all pertinent citation } \\
\text { information }\end{array}$ & $\begin{array}{l}\text { Provides appropriate citations for } \\
\text { articles compared and contrasted } \\
\text { for the assignment }\end{array}$ & $\begin{array}{l}\text { - Presents complete citations in } \\
\text { correct format (e.g., APA, MLA, } \\
\text { etc.) }\end{array}$ \\
\hline
\end{tabular}

Table 2. Accessing needed information effectively and efficiently. Note that the Outcomes are drawn from the 2000 ACRL Standards.

critical thinking component, and student performance can be guided and assessed by the performance indicators and outcomes written into the standard. A few of the outcomes for Standard 3 are presented in Table 3. The last two outcomes listed address the impact of the information on the student's own belief system and previous knowledge. The assignment could easily be modified to incorporate this more personal aspect, requiring the student to write about their personal views with respect to the articles they have compared. An instructor might ask them why they favor one viewpoint over another, or why they reject both. Table 3 relates selected outcomes and measurements to our example assignment.

\section{Standard 4: Using information appropriately to accomplish a specific purpose}

ACRL Standard 4 addresses the appropriate use of information to accomplish a specific purpose. In this particular case the purpose - to write a short paper comparing and contrasting two refereed journal articles - is established at the outset. For this simple assignment the standard provides more help with assessment than with incorporation of additional instructional elements, as illustrated in Table 4. Outcomes include effectively organizing the paper and appropriately quoting and paraphrasing in support of arguments in the final paper.

\section{Standard 5: Using information in an ethical and legal manner}

Finally, ACRL Standard 5 tackles the ethical and legal use of information. At the very least, the student should demonstrate an ability to appropriately document the materials that they are using to complete the assignment. Class discussions can help students to understand what plagiarism is, why it is unethical to present someone else's work as their own, and why it is so important to document appropriately. As discovered in a portfolio assessment project at The University of Akron, instructors should not assume that a statement of conduct on the syllabus or similar instruction in previous courses is sufficient to instill in students a true understanding of plagiarism (Leonard, 2001). If the assignment requests that the students submit a copy of each article, then the discussion of the assignment in class is a good starting point for conversation about copyright and the appropriate and inappropriate use of photocopies. Proper documentation, as seen in Table 5, becomes an ethical issue, changing its focus from an information management issue as in Standard 2. 


\begin{tabular}{|l|l|l|}
\hline Outcome: & Assignment component: & Measurements: \\
\hline Read text and extract main ideas & Compare and contrast & $\begin{array}{l}\text { - Paper effectively compares and } \\
\text { contrasts articles }\end{array}$ \\
\hline Paraphrase correctly & Paraphrase correctly & $\begin{array}{l}\text { Paraphrases when appropriate } \\
\text { - Restates concepts in own words }\end{array}$ \\
\hline $\begin{array}{l}\text { Appropriately acknowledge exact } \\
\text { quotes }\end{array}$ & Quotes correctly & $\begin{array}{l}\text { Uses direct quotes when } \\
\text { appropriate }\end{array}$ \\
\hline $\begin{array}{l}\text { Analyze structure and logic of } \\
\text { arguments }\end{array}$ & Compare and contrast & $\begin{array}{l}\text { - Identifies issues and conclusions } \\
\text { in articles } \\
\text { - Critically evaluates arguments in } \\
\text { articles } \\
\text { - Effectively compares articles } \\
\text { Effectively contrasts articles }\end{array}$ \\
\hline $\begin{array}{l}\text { Determine whether information } \\
\text { gathered fills the information need }\end{array}$ & $\begin{array}{l}\text { Chooses appropriate articles to } \\
\text { compare and contrast }\end{array}$ & $\begin{array}{l}\text { Chooses appropriate articles to } \\
\text { compare and contrast }\end{array}$ \\
\hline Examine differing viewpoints & $\begin{array}{l}\text { Chooses articles with differing } \\
\text { viewpoints }\end{array}$ & $\begin{array}{l}\text { Chooses articles with differing } \\
\text { viewpoints } \\
\text { Accurately identifies differing } \\
\text { viewpoints when comparing } \\
\text { articles }\end{array}$ \\
\hline Accept or reject viewpoint(s) & $\begin{array}{l}\text { Incorporate personal views into } \\
\text { paper }\end{array}$ & $\begin{array}{l}\text { Includes personal viewpoint with } \\
\text { respect to the topic }\end{array}$ \\
\hline
\end{tabular}

Table 3. Critically evaluating information and the sources from which it is gathered. Note that the Outcomes are drawn from the 2000 ACRL Standards.

\begin{tabular}{|l|l|l|}
\hline Outcome: & Assignment component: & Measurements: \\
\hline $\begin{array}{l}\text { Effectively organizes content of } \\
\text { paper }\end{array}$ & Write paper & $\begin{array}{l}\text { - Paper is organized and logical } \\
\text { - Logically compares and contrasts }\end{array}$ \\
\hline $\begin{array}{l}\text { Uses quotes and paraphrasing to } \\
\text { support arguments }\end{array}$ & Write paper & $\begin{array}{l}\text { Uses paraphrasing appropriately } \\
\text { - Uses direct quotes appropriately }\end{array}$ \\
\hline Communicates clearly & Write paper & $\begin{array}{l}\text { - Paper effectively compares and } \\
\text { contrasts articles }\end{array}$ \\
\hline
\end{tabular}

Table 4. Using information appropriately to accomplish a specific purpose. Note that the Outcomes are drawn from the 2000 ACRL Standards

\section{DISCUSSION}

The example assignment presents a number of collaborative opportunities between the faculty member teaching a course and their instruction or subject librarian. A paper or online pathfinder can be developed to guide students through the resources, searches, and information management strategies required by this specific assignment. An alternative to the single-class BI session is for the librarian to conduct one or more very short, very specific, instruction sessions targeted to such concepts as search strategies, using indexing resources to locate articles in refereed journals, and physically locating the journals themselves. The librarian can discuss evaluation of resources used to locate information, such as indexes and abstracting databases, whereas evaluation of subject matter is the bailiwick of the instructor. Ethical use of information is a topic that the instructor and the librarian can introduce from different perspectives, e.g., the librarian can speak about free vs. fee-based access while the instructor might review the appropriate documentation style. If this targeted instruction technique can be managed throughout the course for other library-related assignments, the students will be exposed to a variety of strategies for locating information using the resources provided by the institution.

Our example uses a library-related assignment, but other course activities can foster IL skills development outside of the library. One outcome included under Standard 1 indicates that an information literate student can recognize the need to construct information using raw data. Depending upon the constraints of the course, this could mean actual field collection of data or the gathering and analysis of data from published sources. An exercise using the latter has been successfully implemented as an assignment in an upper level geology course, Groundwater Hydrology. For the exercise, the students are given the address of a property in Ohio and asked to determine how deep a well must be drilled to supply water for the family that lives there. There are many approaches that the students can, and do, take. They may initially visit the library, but there is not sufficient published information to accurately complete the assignment. Instead, they must eventually find drilling well records for nearby wells. In Ohio, this information is available online or by visiting the state Division of Water in Columbus. After they have gathered this data, they must evaluate its quality and 


\begin{tabular}{|l|l|l|}
\hline Outcome: & Assignment component: & Measurements: \\
\hline $\begin{array}{l}\text { Understands issues related to free } \\
\text { vs. fee-based access to information }\end{array}$ & Find articles & $\begin{array}{l}\text { - Differentiates between free and } \\
\text { fee-based services }\end{array}$ \\
$\begin{array}{l}\text { Properly authenticates to remote } \\
\text { resources }\end{array}$ \\
\hline $\begin{array}{l}\text { Demonstrates understanding of } \\
\text { copyright issues and fair use } \\
\text { plagiarism }\end{array}$ & $\begin{array}{l}\text { Compare articles; can add } \\
\text { component requiring submission } \\
\text { of copies of articles }\end{array}$ & $\begin{array}{l}\text { - Properly documents sources } \\
\text { - Properly credits authors } \\
\text { - Defines "fair use" concept }\end{array}$ \\
\hline $\begin{array}{l}\text { Uses appropriate documentation } \\
\text { style correctly and consistently }\end{array}$ & Properly documents sources & $\begin{array}{l}\text { - Properly documents sources } \\
\text { - Properly cites direct quotations } \\
\text { - Uses paraphrasing appropriately }\end{array}$ \\
\hline
\end{tabular}

Table 5. Using information in an ethical and legal manner. Note that the Outcomes are drawn from the 2000 ACRL Standards.

relevance to the problem. They must then analyze the data through cross-sections, tables, or statistical methods to answer the assignment. The entire assignment builds skills in Information Literacy and has been well received by the students.

\section{CONCLUSIONS}

Geoscience students face a constantly growing world of information. This provides many opportunities, but also brings challenges for finding, sorting, evaluating, storing, and conveying that information. Geoscience teachers, likewise, are challenged by forever-changing sources and technologies. Acknowledging information literacy skills as a crucial part of the overall education and preparation for "life after college" of a student, and conscientiously incorporating IL activities into the geoscience curriculum, opens new avenues of communication between the geoscience faculty and the library faculty. IL skills enable the student to make better judgments about the authenticity, veracity, validity, and reliability of the information they encounter. This is not limited simply to the information a student requires to complete a course or a degree - it also pertains to making informed decisions throughout life.

\section{ACKNOWLEDGEMENTS}

We are grateful to JoAnn Calzonetti, David Steer, and Marie Toth for their suggestions on an early version of this paper. Reviewers Martin Miller and Karen Havholm provided important comments that improved the paper.

\section{REFERENCES}

American Library Association, 1989, Presidential Committee on Information Literacy Report, Accessed May 25, 2001 via the WWW, http://www.ala.org/acrl/nili/ilit1st.html

Association of College and Research Libraries, 2000, Information Literacy Competency Standards for Higher Education, Accessed June 2, 2002 via the WWW: http://www.csusm.edu/acrl/il/toolkit/ standards.html

Bichtelor, J., 1985, Library instruction for geology students, Journal of Geological Education, v. 33, p. 281-283.

Leonard, J. K., 2001, Report: Portfolio Assessment Project - Year II (May 21-June 1, 2001), University of Akron [Internal document], $29 \mathrm{p}$.

Stoan, S.K., 1984, Research and library skills: An analysis and interpretation, College and Research Libraries, v. 45 , p. $99-109$. 